\title{
Seismic fragility analysis of composite frame structure based on performance*
}

\author{
Jingbo Liu ${ }^{1, \star}$ Yangbing Liu $^{2}$ and Heng Liu ${ }^{1}$ \\ ${ }^{1}$ Department of Civil Engineering, Tsinghua University, Beijing 100084, China \\ ${ }^{2}$ College of Civil Engineering, Chongqing University, Chongqing 400045, China
}

\begin{abstract}
Steel-concrete composite structures that share the advantages of both steel structure and concrete structure have been developed rapidly and used widely. It has been a popular structure in high-rise buildings in recent years. Although more and more composite structures have been used in earthquake area, only a few literatures about fragility analysis of this type of structure are available. In this paper, a fragility analysis method based on performance is proposed, in which both the uncertainty due to variability in structures and ground motion are considered. Seismic fragility analysis is performed for a 15 -story composite beam-concrete-filled square steel tube column frame by the proposed method. The top-drift-angle and the story-drift-angle are used as quantitative indexes to define the four different performance levels. Then seismic demand probability analysis is carried out and fragility curves are derived to assess the seismic performance of this type of structure.
\end{abstract}

Key words: composite structure; performance level; seismic demand; fragility curve CLC number: P315.9 Document code: A

\section{Introduction}

Wenchuan earthquake in China caused damage and collapse of a large number of buildings, resulting in a series of social and economic problems. So the seismic risk assessment has been increasingly recognized. The seismic risk assessment mainly includes three aspects: seismic risk analysis, seismic fragility analysis and seismic loss assessment, in which the seismic fragility analysis is to predict the probability of different structural damage state caused by different level of ground motion. During an earthquake, life and property losses are directly originated from the damaged and collapsed buildings, so the seismic fragility analysis of buildings plays a very important role in earthquake prevention and disaster reduction. On one hand, it can predict the seismic disaster before earthquakes and provide reference for designers to improve structural seismic capacity; on the other hand, it can be used to evaluate the loss after earthquakes and offer measures to avoid/reduce personnel casualties.

\footnotetext{
* Received 3 July 2009; accepted in revised form 19 November 2009; published 10 February 2010.

^ Corresponding author. e-mail: liujb@tsinghua.edu.cn

(C) The Seismological Society of China and Springer-Verlag Berlin Heidelberg 2010
}

With wide application of steel-concrete composite structures, their dynamic performance and seismic behavior attracts considerable interests. And the performance-based fragility analysis is of significance in reasonably estimating structural damages in an earthquake and in taking aseismic measures to control damage and economic loss within an expecting range. Though the steel-concrete structure has been widely used in recent years, sufficient data are unavailable on seismic damage. Therefore, for composite structures, the analysis method is the only feasible approach to obtain seismic fragility curve for the present (Hwang and Liu, 2004)

The fragility of reinforced concrete structures and bridges has been thoroughly studied. Park et al (2009) analyzed the seismic fragility of low-rise unreinforced masonry structures. Schotanus et al (2004) analyzed the seismic fragility of reliability problems for the timevarying system of the steel-concrete frame. Combining both seismic environment characteristic and site effect, Wen et al (2006) proposed a method to analyze seismic fragility of reinforced concrete structures. Chang (2006) proposed a global seismic fragility analysis method based on reliability and performance, and a local seismic fragility analysis method based on reliability and sensitivity. Aiming at the areas lack of seismic damage data 
of bridges, Hwang and Liu (2004) proposed a systematic analysis method for fragility curve of reinforced concrete bridges under seismic action, considering the uncertainty in seismic action, local site, and bridge parameters. For bridge piers along highway, Karim and Yamazaki (2001) suggested a method to develop theoretical fragility curve by numerical simulation; besides, they proposed a simplified method to obtain fragility curve for highway bridges (Karim and Yamazaki, 2004).

In this paper, for the composite frame structure consisting of composite beam and concrete filled square steel tube column, the seismic fragility based on performance is analyzed to obtain the seismic fragility curve; then, the damage state and the seismic behavior of the structure under different-level earthquakes are analyzed and evaluated.

\section{Structure model}

The study object is a 15-story composite frame structure: the ground floor is 4.5 meter in height, and others are 3.6 meter in height, the total height is $54.9 \mathrm{~m}$; the plan and elevation of the structure are shown in Figure 1. Roof and floor panels are 140 mm-thick C30 concrete slab; the transverse sections of steel beams are 750 $\mathrm{mm} \times 300 \mathrm{~mm} \times 13 \mathrm{~mm} \times 24 \mathrm{~mm}$, and the longitudinal sections are $700 \mathrm{~mm} \times 300 \mathrm{~mm} \times 13 \mathrm{~mm} \times 24 \mathrm{~mm}$; the welded beams are made of Q235 steel. The side length of concrete-filled square steel tube column section is $600 \mathrm{~mm}$, for which C40 concrete and Q345 steel tube are used; the columns from 1 st to 5 th floor are $20-\mathrm{mm}$-thick steel tube, while the other columns are $15-\mathrm{mm}$-thick. Floor dead load and roof dead load are $4.5 \mathrm{kN} / \mathrm{m}^{2}$, while live load is $2.0 \mathrm{kN} / \mathrm{m}^{2}$. Owing to the symmetry, the structure is simplified to a plane model and the frame at axis (4) is analyzed. The composite beams are designed by full shear connection. The composite effect of floor is considered simultaneously.

The non-linear structural analysis software SAP2000 is employed to carry out pushover analysis and elastoplastic dynamic time history analysis. Concrete slabs are modeled by shell elements; beams and columns are modeled by beam elements. The non-linearity of frame structure is mainly embodied in beams and columns. In pushover analysis, beams are modeled by M3 hinge with unidirectional bending, in which only non-linearity in bending is considered. In order to study axial and bending non-linearity as well as their mutual interaction, columns are modeled by axial force-bending moment hinge (PM hinge). For the composite beams, the moment-curvature curve adopts the four poly-line model (Guo, 2007); for the concrete-filled square tube columns, the moment-curvature curve and the axial force-bending moment yielding curve is determined in terms of Liu (2009). Figure 2 a presents the moment $(M)$ versus curvature $(\varphi)$ skeleton curve of the composite beams at axis (4); Figures $2 \mathrm{~b}$ and $2 \mathrm{c}$ show the axial force $(N)$ versus bending moment $(M)$ yielding curve of the columns and the moment versus curvature $(\varphi)$ curves for different axial compression ratio $n$, respectively. In elasto-plastic dynamic time history analysis, the kinematic hysteretic model is adopted to simulate the concrete-filled square tube columns, while the Takeda plastic hysteretic model is used to describe the composite beams (Civil King Software Technology Co. Ltd and China Institute of

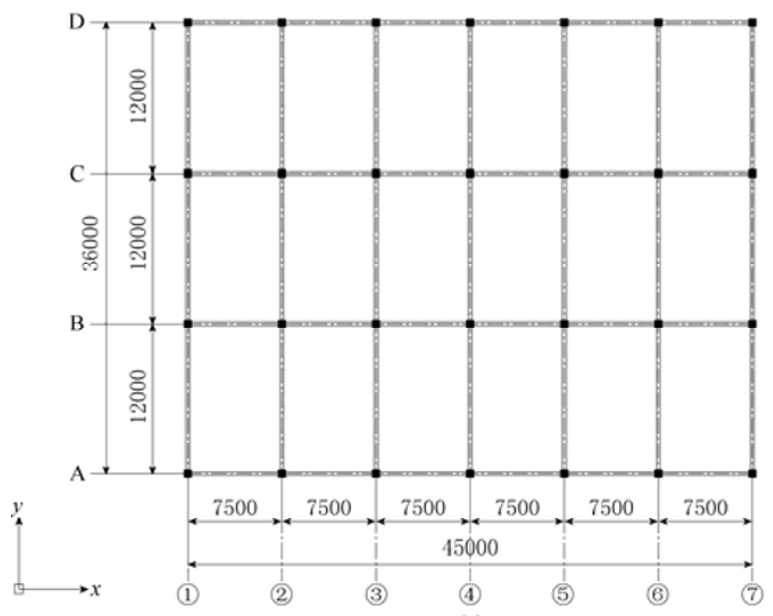

(a)

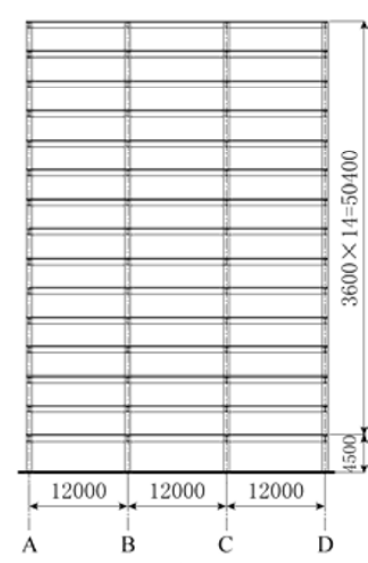

(b)

Figure 1 Layout of the structure in plan (a) and elevation (b) where the figures are in unit of mm. 


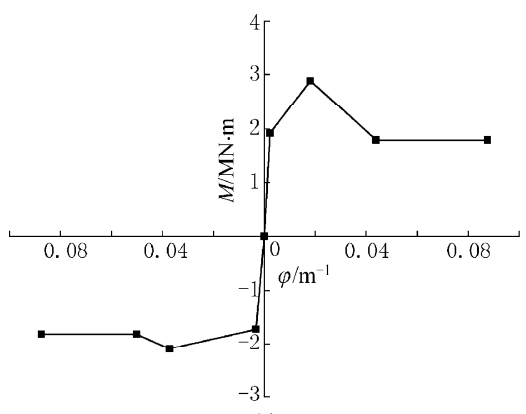

(a)

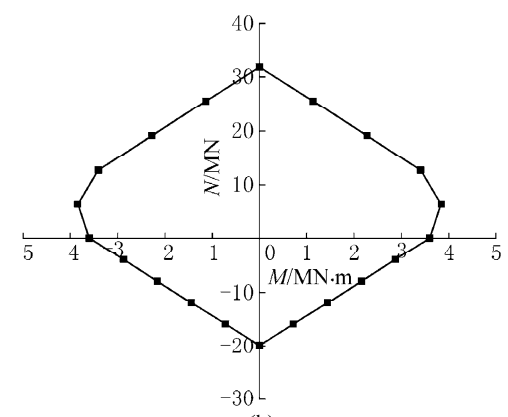

(b)

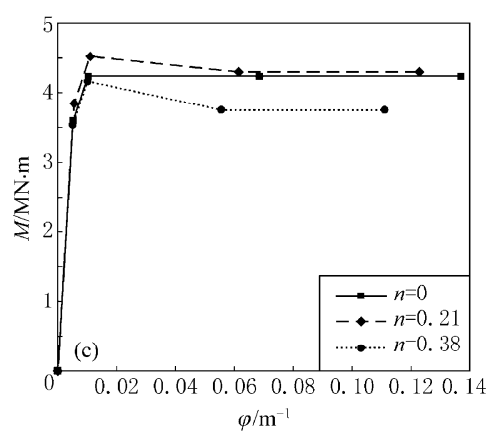

Figure 2 Plastic hinge model of the beam and column. (a) The 4-poly moment $(M)$ versus curvature $(\varphi)$ curve of the beam; (b) The axial force $(N)$ versus bending moment $(M)$ yielding curve of the column; (c) The $M$ - $\varphi$ curve of the column for different axial compression ratio $n$.

Building Standard Design \& Research, 2006).

\section{Fragility analysis methods}

At present, the seismic fragility curves are available in many ways (Erberik and Elnashai, 2004). There are many uncertainties in seismic fragility analysis, such as material property, geometric size, boundary condition, seismic action and analysis model (Zhao et al, 1999). These uncertainties will inevitably result in randomness of structural dynamic response. Due to their effect on performance, only uncertainties in material strength and ground motion are considered, which can reflect the effect of structural non-linearity and make the computational cost more acceptable.

For the seismic fragility analysis based on performance, the pushover method is employed to determine the seismic performance level, and elasto-plastic dynamic time history analysis method is used to analyze probabilistic seismic demand in this paper.

\section{Determination of structural seismic performance levels based on members}

\subsection{Structural performance levels and damage state levels}

The definition of seismic performance levels, namely, performance indexes, affect shape and value of the structural fragility curve significantly. A seismic performance level describes a limiting damage state corresponding with the expected maximum damage for earthquake ground motion. There are many ways to categorize damage states. Referring to Code for Classification of Earthquake Damage to Buildings and Special Structures (General Administration of Quality Supervi- sion, Inspection and Quarantine of the People's Republic of China, 2009), damage state includes five levels in this paper: basically good, slight damage, middle damage, severe damage and collapse; meanwhile, the corresponding structural performance levels are specified as normal occupancy (NO), immediate occupancy (IO), life safety (LF) and collapse prevention (CP). As far as the multi-story and high-rise frame structures are concerned, the structural deformation can reflect the global structural performance better than the bearing capacity does. Accordingly, the top-drift-angle $\left(\theta_{\mathrm{T}}\right)$ and the story-drift angle $\left(\theta_{\mathrm{S}}\right)$ are regarded as quantitative indexes to establish the relationship between damage levels and structural performance levels. Table 1 shows the performance levels and the limit values of the corresponding quantitative indexes; Table 2 shows the relationship between damage states and performance indexes. Currently, two methods, respectively, based on global structural performance and member performance, are commonly used to determine the limit values of quantitative indexes in the world (FEMA, 2000). The former obtains the limit values according to actual seismic damages of different types of structures, a large number of experiment results and engineering examples, which gives the same limit value for the same type of structure and provides the approximate estimation of structural performance for the same type structure; and the latter determines the global structural performance levels according to the damage state of members, in which the value of a performance level may be different for different structures of the same type. So the latter can truly evaluate structural performance levels. The method based on member performance is adopted to determine the limit values of quantitative indexes. 
Table 1 Performance levels and quantitative indexes

\begin{tabular}{|c|c|c|}
\hline Performance level & Requirement & Limit value of quantitative indexes \\
\hline Normal occupancy (NO) & No or few structural and non-structural members are damaged & $L_{\mathrm{S} 1}$ \\
\hline Immediate occupancy (IO) & Minor repair is needed for structural and non-structural members & $L_{\mathrm{S} 2}$ \\
\hline Life safety (LF) & Structure remains stable and has enough capacity & $L_{\mathrm{S} 3}$ \\
\hline Collapse prevention $(\mathrm{CP})$ & Structure does not collapse; the damage is acceptable & $L_{\mathrm{S} 4}$ \\
\hline
\end{tabular}

Table 2 Relationship between structural performance levels and quantitative indexes

\begin{tabular}{c|cccc}
\hline Damage state & Basically good & Slight damage & Middle damage & Severe damage \\
Quantitative index & $\leq L_{\mathrm{S} 1}$ & $\left(L_{\mathrm{S} 1}, L_{\mathrm{S} 2}\right.$ & $\left(L_{\mathrm{S} 2}, L_{\mathrm{S} 3}\right]$ & Collapse \\
\hline
\end{tabular}

\subsection{Limit values of quantitative indexes}

As a new structural type, the steel-concrete composite structure is different from the common reinforced concrete structure and the steel frame in mechanical property and deformation characteristic. Accordingly, a laterally distributed loading with inverted triangle pattern based on the first mode is adopted to perform the pushover analysis, and the limiting structural damage state is defined by the classification method (General Administration of Quality Supervision, Inspection and Quarantine of the People's Republic of China, 2009). Figure 3 shows the relation curve between base shear and top displacement by the pushover analysis for the composite frame structure. The feature points in Figure 3 correspond to the four limiting damage states (performance levels), and the corresponding damage states of structural

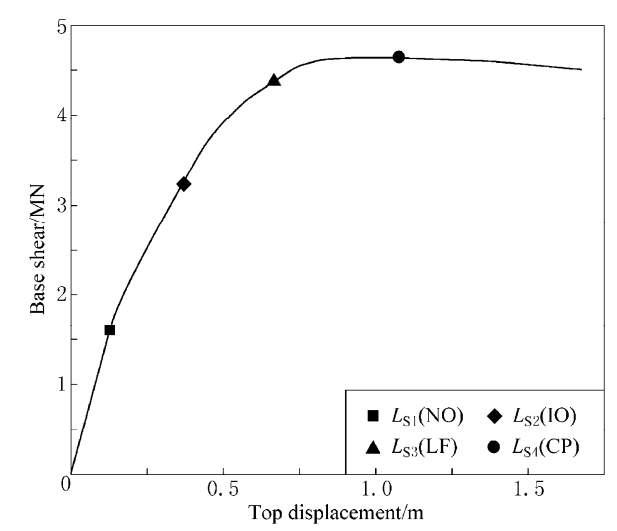

Figure 3 Capacity curve and definition of performance levels. members and the quantitative indexes are given in Table 3.

The horizontal story-drift-angle limit is determined by the following method (Erberik and Elnashai, 2004; Hueste and Bai, 2007): draw the relation curve between story-drift-angles and story shear for each story based on the pushover analysis, and mark the damage state of members on the curve; then determine the limit value of horizontal story-drift-angles for different performance level according to the damage state of each story and choose the minimum value as horizontal story-drift-angle limit of global structural performance. From the results, it can be found that the bottom story-drift-angle is the minimum. So the bottom story is chosen as the key story to define the horizontal story-drift-angle limit of global structural performance. The yielding state and the ultimate state are used to describe the elasto-plastic deformation characteristic of beams and columns. Figure 4 shows the process of determining the story-drift-angle limit. Figure $4 \mathrm{a}$ is the relation curve between the story shear and the bottom story-drift-angle, where the feature points represent the elasto-plastic deformation states that the corresponding structural member reaches. For clarity, only some typical feature points are given. Figures $4 \mathrm{~b}$ and $4 \mathrm{c}$ show the sequence that the plastic hinges reach the yielding and the ultimate state, respectively.

According to damage state of the bottom beams and columns, the story-drift-angles corresponding to $\mathrm{Y}_{1}$, $\mathrm{Y}_{2}, \mathrm{U}_{3}$ and $\mathrm{U}_{6}$ are used as different structural performance levels of the structures, as shown in Table 4.

Table 3 Definition of ultimate state and values of quantitative indexes of top displacement

\begin{tabular}{|c|c|c|c|}
\hline Performance level & Damage state & $\begin{array}{l}\text { Top displacement } \\
\text { limit }\end{array}$ & $\begin{array}{l}\text { Composite beam-concrete-filled } \\
\text { square tube column frame }\end{array}$ \\
\hline Normal occupancy (NO) & One end of a beam yields, the other members are intact & $L_{\mathrm{S} 1}$ & $1 / 422$ \\
\hline Immediate occupancy (IO) & $\begin{array}{l}\text { One end of the beams from } 1-7 \text { floor yields; about } 20 \% \\
\text { members are damaged slightly }\end{array}$ & $L_{\mathrm{S} 2}$ & $1 / 148$ \\
\hline Life safety (LF) & $\begin{array}{l}\text { About } 80 \% \text { members are damaged, where one end of } 50 \% \\
\text { beams reaches the ultimate state, the bottom end of the beams } \\
\text { yields; the stiffness of the structure reduces greatly }\end{array}$ & $L_{\mathrm{S} 3}$ & $1 / 82$ \\
\hline Collapse prevention $(\mathrm{CP})$ & $\begin{array}{l}\text { The bottom end of beams and both ends of } 50 \% \text { beams reach } \\
\text { the ultimate state, top end of some columns yields }\end{array}$ & $L_{\mathrm{S} 4}$ & $1 / 51$ \\
\hline
\end{tabular}




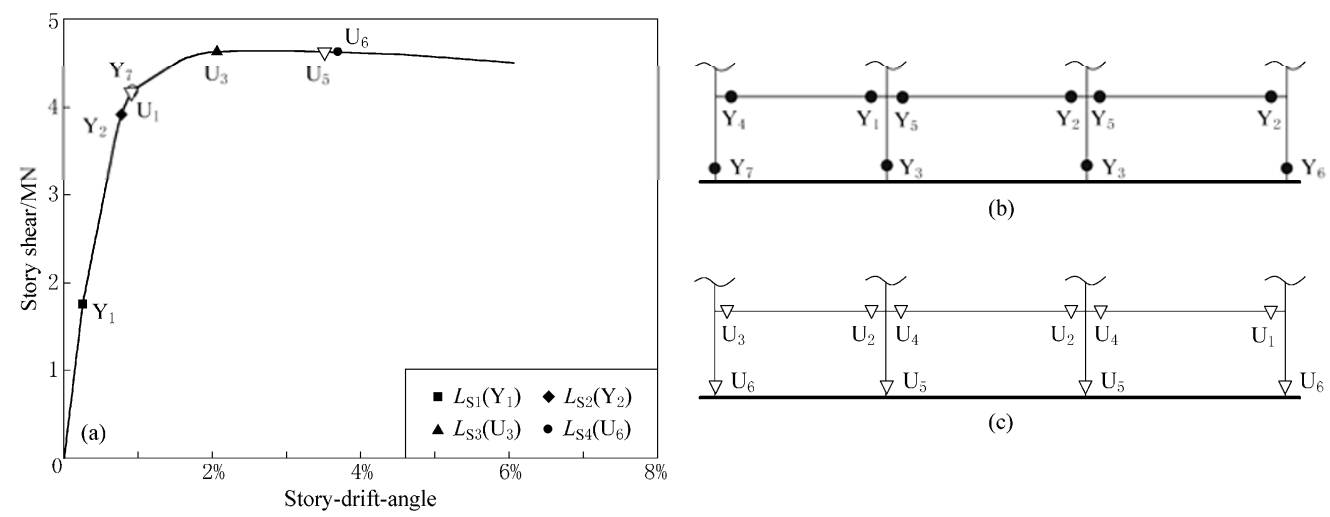

Figure 4 Determination of the story-drift-angle limit based on story damage state where letter "Y" denotes yielding, and letter "U" denotes ultimate. (a) Bottom story-drift-angle versus story shear; (b) Bottom plastic hinges reach yielding state in numerical order; (c) Bottom plastic hinges reach the ultimate state in numerical order.

Table 4 Limiting damage state definition and values of story-drift-angle quantitative indexes

\begin{tabular}{|c|c|c|c|}
\hline Performance level & Bottom story damage state & Story-drift-angle limit & $\begin{array}{c}\text { Composite beam-concrete-filled } \\
\text { square tube column frame }\end{array}$ \\
\hline Normal occupancy (NO) & Only plastic hinge $Y_{1}$ emerges & $L_{\mathrm{S} 1}$ & $1 / 391$ \\
\hline Immediate occupancy (IO) & $\begin{array}{l}\text { Plastic hinge } \mathrm{Y}_{2} \text { emerges, the right end of beam yields, mem- } \\
\text { bers can be used after minor repair }\end{array}$ & $L_{\mathrm{S} 2}$ & $1 / 122$ \\
\hline Life safety (LF) & $\begin{array}{l}\text { Plastic hinge } U_{3} \text { emerges, the left end of beam and both ends } \\
\text { of the left beam reach the ultimate state; all beams do not } \\
\text { reach the ultimate state, the structure has a certain capacity }\end{array}$ & $L_{\mathrm{S} 3}$ & $1 / 48$ \\
\hline Collapse prevention (CP) & $\begin{array}{l}\text { Plastic hinge } \mathrm{U}_{6} \text { emerges, both ends of beams and bottom end } \\
\text { of columns reach the ultimate state; the structural capacity } \\
\text { starts to decrease. }\end{array}$ & $L_{\mathrm{S} 4}$ & $1 / 28$ \\
\hline
\end{tabular}

Comparing two groups of quantitative indexes in Tables 3 and 4, it can be seen that the limit values of story-drift-angle are larger than those of top-drift-angle for all performance levels, which coincides with actual situations. The performance indexes can be determined by the ultimate state of the structure itself and the requirement of owner or user as well, for example, control structural deformation within a certain range for comfort Consequently, the performance levels can be adjusted to meet the demand for owners.

\section{Probabilistic seismic demand analysis}

\subsection{Structure-ground motion samples}

Under seismic action, the randomness of structural response is mainly caused by uncertainties in ground motion and the structure itself. To study the fragility of the steel-concrete composite frame structure subjected to near-field strong ground motion, 10 strong ground motion records from the Jiji (Chi-Chi) earthquake in Taiwan and six records from other earthquakes are used as seismic input. The epicentral distance is $7.1-71.0 \mathrm{~m}$, and the peak ground acceleration is $1.6-4.2 \mathrm{~m} / \mathrm{s}^{2}$. Figure
5 shows the acceleration response spectra of these 16 ground motion records with $5 \%$ damping ratio, which are adjusted proportionately to be $1.0 \mathrm{~g}$ at natural period. The uncertainties in ground motion are contained in discreteness of these response spectra.

The uncertainties in structure itself mainly come from that in building material, that is, the variability of steel and concrete. The mean and coefficient of variation for steel yielding strength $f_{\mathrm{y}}$ and the axial compressive strength $f_{\mathrm{c}}$ of concrete are presented in Table 5. For the four random variables in Table 5, 10 samples are chosen by Latin hypercube sampling method. Then the four groups of samples are sorted randomly to form $10 \mathrm{com}$ binations of structure samples for finite-element analysis. The peak acceleration of each ground motion record is proportionately adjusted to $0.05 \mathrm{~g}, 0.1 \mathrm{~g}, 0.2 \mathrm{~g}, 0.3 \mathrm{~g}, 0.4 \mathrm{~g}$, $0.5 \mathrm{~g}, 0.6 \mathrm{~g}$ and $0.7 \mathrm{~g}$, and then assigned to the 10 structure samples. Consequently, total 1280 computational structure-ground motion samples are formed.

\subsection{Structural probabilistic seismic demand analysis}

For each structure-ground motion sample, the non-linear dynamic time history analysis is performed to 


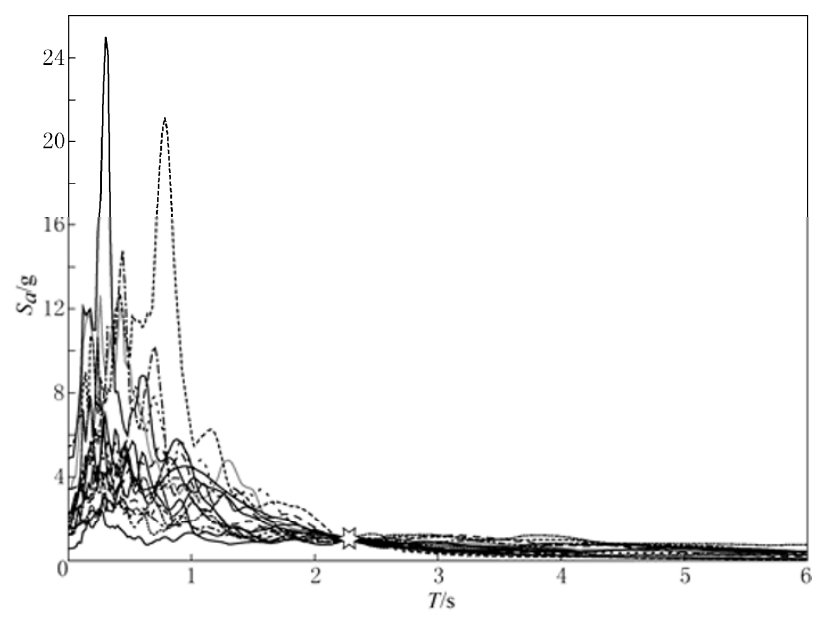

Figure 5 Response spectra of 16 ground motion records.

Table 5 Statistical information of random variables

\begin{tabular}{lrcl}
\hline Item & $\begin{array}{r}\text { Mean } \\
\text { /MPa }\end{array}$ & $\begin{array}{c}\text { Coefficient of } \\
\text { variation }\end{array}$ & Pattern of distribution \\
\hline Column steel $f_{\mathrm{y}}$ & 389.90 & 0.07 & Lognormal distribution \\
Beam steel $f_{\mathrm{y}}$ & 270.61 & 0.08 & Lognormal distribution \\
Column concrete $f_{\mathrm{c}}$ & 33.39 & 0.12 & Normal distribution \\
Floor concrete $f_{\mathrm{c}}$ & 26.11 & 0.14 & Normal distribution \\
\hline
\end{tabular}

obtain the structural seismic demand that varies with the peak ground acceleration (PGA), as shown in Figure 6. Figures $6 \mathrm{a}$ and $6 \mathrm{~b}$ show the data distribution of the maximum top-drift-angle and that of the maximum sto-

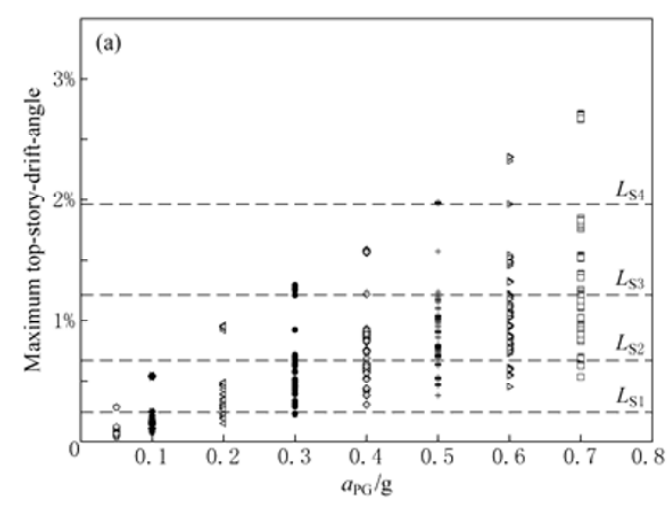

Figure 6 Relationships between structural seismic demand and PGA denoted by $a_{\mathrm{PG}}$. (a) The maximum top-drift-angle demand; (b) The maximum story-drift-angle demand.

By statistical analysis of the maximum top-driftangle $\left(\theta_{T \max }\right)$ and the maximum story-drift- angle $\left(\theta_{\mathrm{S} \max }\right)$, the mean and coefficient of variation for different PGAs are obtained, shown in Figure 6. For the composite frame structure, Figure 7 gives the lognormal probability density function of the seismic demand $\left(\theta_{\mathrm{T} \max }\right.$ and $\left.\theta_{\text {Smax }}\right)$ when PGA is taken as $0.4 \mathrm{~g}$. The vertical dashed lines denote different structural performance levels, ry-drift-angle respectively, for the composite beam-concrete-filled square steel tube column frame. In Figure 6, each data point represents the structural response for a structure-ground motion sample, which is derived by nonlinear dynamic analysis. There are 1280 data-points totally, and each column of data points are structural response under the same PGA action. From down to up, the horizontal dashed lines represent the structural performance levels $L_{\mathrm{S} 1}, L_{\mathrm{S} 2}, L_{\mathrm{S} 3}$ and $L_{\mathrm{S} 4}$, whose values correspond to structural quantitative indexes defined in Tables 3 and 4 . These dashed lines that represent different structural performance levels are also boundaries dividing different structural damage states. For these structural-ground motion samples, the damage states are defined as basically good, slight damage, middle damage, severe damage and collapse. Based on the studies of Li and Cheng (2004) and statistical analysis, the maximum top-drift-angle and maximum storydrift-angle are lognormal distributed for the samples with same PGA. Consequently, the probability density function of structural response $u$ (including the maximum top-drift-angle and the maximum story-drift-angle) is expressed as a lognormal distribution function, which is defined by the logarithmic mean $\bar{\mu}_{\ln u}$ and the logarithmic standard deviation $\bar{\sigma}_{\ln u}$.

$$
u=\ln \left(\bar{\mu}_{\ln u}, \bar{\sigma}_{\ln u}\right)
$$

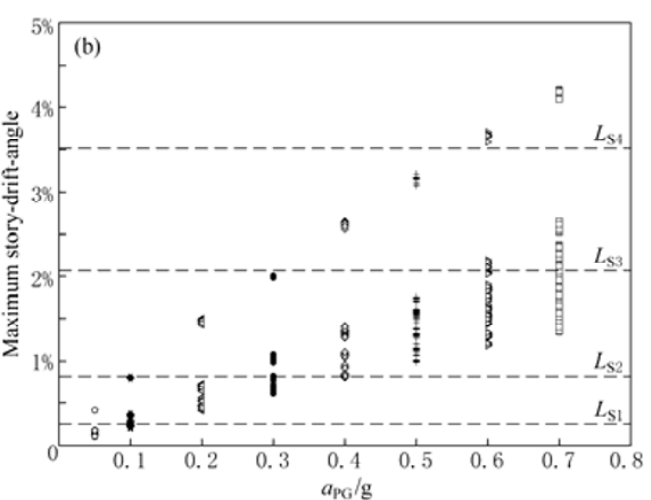

which divide the area enclosed by the probability function and the horizontal axis into five sub areas: basically good, slight damage, middle damage, severe damage, and collapse. From Figure 7 we can see that, when PGA is $0.4 \mathrm{~g}$, no matter what quantitative index is adopted, the probability that structural demand exceeds the limit value $L_{\mathrm{S} 1}$ is very large, while exceeds the limit value $L_{\mathrm{S} 3}$ is very small. In other words, structures will rarely keep 
Table 6 Statistical information of structural demand

\begin{tabular}{cccc}
\hline \multirow{2}{*}{ PGA/g } & \multicolumn{3}{c}{ Composite beam-concrete filled steel tube column frame } \\
\cline { 2 - 4 } & Mean of maximal top-drift-angle & Coefficient of variation & Mean of maximal story-drift angle \\
\hline 0.05 & $0.095 \%$ & 0.563 & $0.158 \%$ \\
0.1 & $0.189 \%$ & 0.549 & $0.315 \%$ \\
0.2 & $0.365 \%$ & 0.476 & $0.619 \%$ \\
0.3 & $0.530 \%$ & 0.433 & $0.910 \%$ \\
0.4 & $0.691 \%$ & 0.411 & 0.449 \\
0.5 & $0.852 \%$ & 0.422 & 0.399 \\
0.6 & $1.006 \%$ & 0.432 & 0.356 \\
0.7 & $1.159 \%$ & 0.443 & 0.351 \\
\hline
\end{tabular}
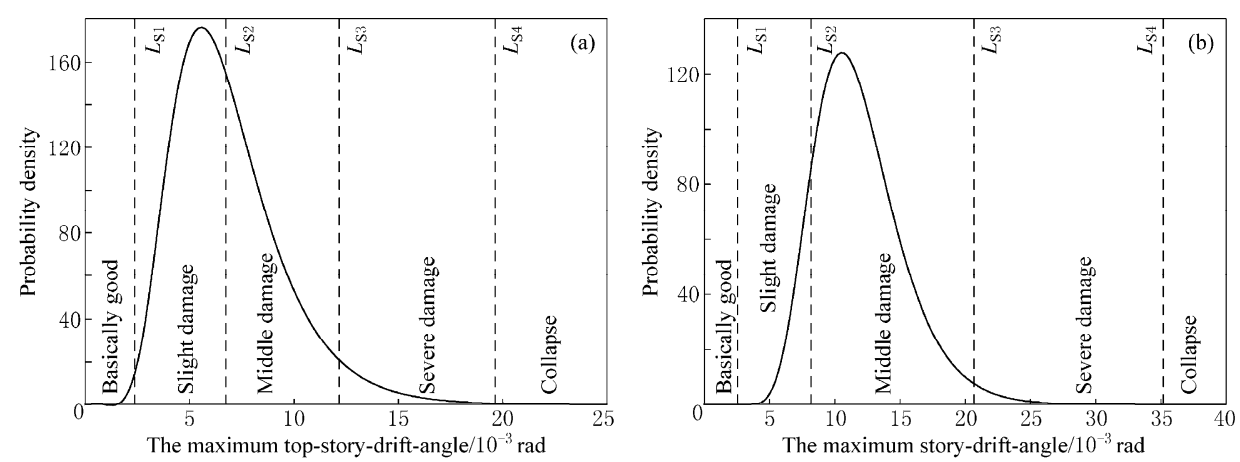

Figure 7 Probability density functions of lognormal distributions for structural seismic demand (PGA is $0.4 \mathrm{~g}$ ). (a) The maximum top-drift-angle; (b) The maximum story-drift-angle.

rarely keep intact or be damaged severely. And Figure 6 shows that the data points mostly distribute between $L_{\mathrm{S} 1}$ and $L_{\mathrm{S} 3}$ when PGA is $0.4 \mathrm{~g}$, which is consistent with Figure 7.

\section{Formation of fragility curves}

The structural fragility curve represents the probability that the structural demand exceeds the specified damage state under different seismic action. In terms of the definition of structural performance level and the probability distribution of structural seismic demand in this paper, the probability $P\left(u \mid a_{\mathrm{PG}}>L_{\mathrm{S} i}\right)$ that the structural demand $u$ exceeds the limit value $L_{\mathrm{S} i}$ for different PGAs can be solved by

$$
P\left(u \mid a_{\mathrm{PG}}>L_{\mathrm{S} i}\right)=1-\Phi\left(\frac{\ln L_{\mathrm{S} i}-\bar{\mu}_{\ln u \mid a_{\mathrm{PG}}}}{\bar{\sigma}_{\ln u \mid a_{\mathrm{PG}}}}\right),
$$

where $a_{\mathrm{PG}}$ represents value of PGA, $\bar{\mu}_{\mathrm{ln} u \mid a_{\mathrm{PG}}}$ and $\bar{\sigma}_{\ln u \mid a_{\mathrm{PG}}}$ denote the logarithmic average value and the logarithmic standard deviation of the structural demand obtained from statistical analyses. $L_{\mathrm{S} i}$ denotes the limit values of quantitative indexes corresponding to the four performance levels, specified by Tables 3 and 4 , and $i=$ $1,2,3,4 ; \Phi(\cdot)$ represents standard normal distribution function.

For the composite beam-concrete filled steel tube column frame structure, the seismic fragility curve described with the top-drift-angle and the story-drift-angle is obtained, as shown in Figure 8. In the figure, the $x$-coordinate indicates the peak ground acceleration, denoted as $a_{\mathrm{PG}}$; and the $y$-coordinate indicates the probability that the structural demand exceeds a performance level.

For different quantitative index, there is obvious difference in shape of the seismic fragility curve between Figure 8a and Figure 8b. As quantitative index, the top-drift-angle can illustrate the global structural performance and global damage state well, but is not sensitive to the possible story deformation concentration. The story-drift-angle can not only illustrate the structural performance well, but also reflect the story deformation concentration very well. Because of simple concept and convenient application, the story-drift-angle is used more widely in engineering projects.

\section{Conclusions}

This paper presents a fragility analysis method based on performance. Not only the uncertainties in structure itself but also those in ground motion are 

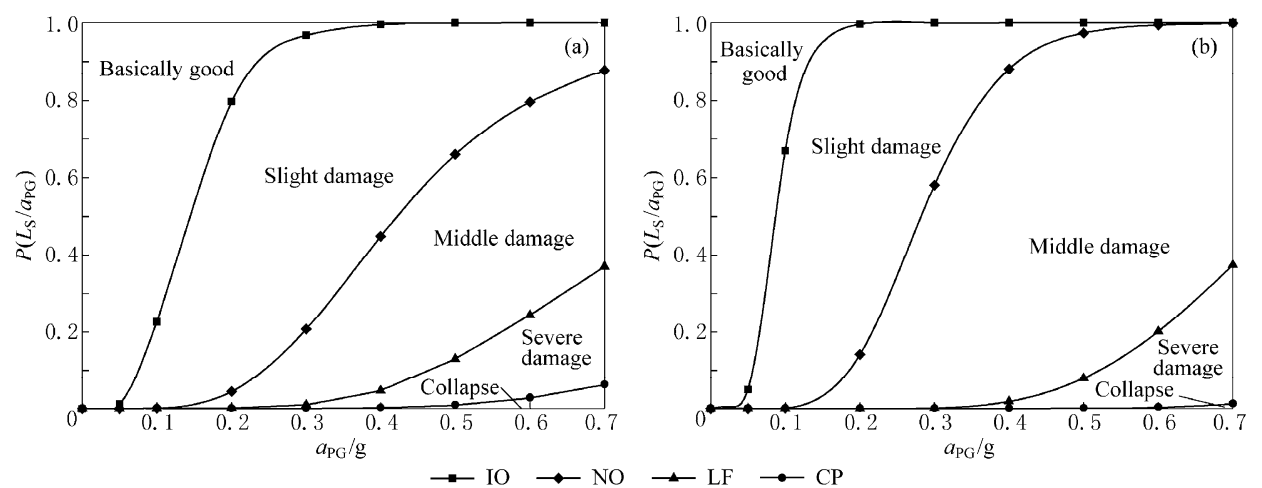

Figure 8 Seismic fragility curves of composite beam-concrete filled steel tube column frame derived by top-drift-angle (a) and story-drift-angle (b).

considered, the method is applicable for the seismic fragility analysis of various structures. The structural seismic performance levels based on members are defined, and the top-drift-angle and story-drift-angle are adopted as two quantitative indexes to develop the relationship between structure damage levels and performance levels. For the composite beam-concrete-filled square steel tube column frame structure, the density function of structural demand is obtained for different PGA, in terms of probabilistic seismic demand analysis; the probability that structural demand exceeds a performance level is computed for different PGA, thus the structural seismic fragility curve varying with PGA is obtained. For the quantitative index of story-drift-angle, the structural fragility curve is acquired based on the most disadvantageous story-drift-angle, which means the results tend to be safe.

Based on the structural seismic fragility curve, the damage probability can be obtained for an earthquake ground motion, which provides the basis for loss assessment of earthquake disasters. Moreover, according to the seismic fragility curves for a region, the regional seismic fragility matrix can be formed, which can be used for the earthquake prevention and disaster reduction plan. Due to limit of space, only PGA is employed as a ground motion parameter to describe the structural response and fragility curve in this paper. Certainly the other ground motion parameters, such as acceleration response spectrum and displacement response spectrum corresponding to the natural period, can be adopted to study the structural fragility. And further research is needed to find a better ground motion parameter, which have general applicability and small discreteness for structural response.

\section{References}

Chang Z M (2006). Nonlinear Seismic Reliability and Fragility Analysis of RC Structures. Master Dissertation, Harbin University of Industry, Harbin, 94-101 (in Chinese with English abstract)

Civil King Software Technology Co. Ltd and China Institute of Building Standard Design \& Research (2006). SAP2000 Analysis Reference Manual for Chinese Version. China Communications Press, Beijing, 57-60 (in Chinese).

Erberik M A and Elnashai A S (2004). Fragility analysis of flat-slab structures. Eng Struct 26(7): 937-948.

Federal Emergency Management Agency (FEMA) (2000). Prestandard and Commentary for the Seismic Rehabilitation of Buildings (FEMA 356). Building Seismic Safety Council for the Federal Emergency Management Agency, Washington D.C., 1-8-1-22.

General Administration of Quality Supervision, Inspection and Quarantine of the People's Republic of China (2009). GB/T 24335-2009: Code for Classification of Earthquake Damage to Buildings and Special Structures. Standards Press of China, Beijing, 1-2 (in Chinese).

Guo B (2007). Aseismic Performance Analysis of Composite Frame Structures. Master Dissertation, Tsinghua University, Beijing, 66-68 (in Chinese with English abstract).

Hueste M B D and Bai J W (2007). Seismic retrofit of a reinforced concrete flat-slab structure: Part II-seismic fragility analysis. Eng Struct 29(6): 1 178-1 188.

Hwang H and Liu J B (2004). Seismic fragility analysis of reinforced concrete bridges. China Civil Eng J 37(6): 47-51 (in Chinese with English abstract).

Karim K R and Yamazaki F (2001). Effect of earthquake ground motions on fragility curves of highway bridge piers based on numerical simulation. Earthq Eng Struct Dynam 30(12): 1 839-1 856.

Karim K R and Yamazaki F (2004). A simplified method of constructing fragility curves for highway bridges. Earthq Eng Struct Dynam 32(10): 1603-1 626.

Li G and Cheng G D (2004). Seismic Design Based on Structural Performance - Theory, Method and Application. Science Press, Beijing, 103-124 (in Chinese).

Liu Y B (2009). Research on Seismic Performance and Fragility Analysis for Steel-Concrete Composite Structural Systems. PhD Dissertation, Tsinghua University, Beijing, 21-38 (in Chinese with English abstract).

Park J, Towashiraporn P, Craig J I and Goodno B J (2009). Seismic fragility analysis of low-rise unreinforced masonry structures. Eng Struct 31(1): $125-137$.

Schotanus M I J, Franchin P, Lupoi A and Pinto P E (2004). Seismic fragility analysis of 3D structures. Struct Saf 26(4): 421-441.

Wen Z P, Gao M T, Zhao F X, Li X J, Lü H S and He S L (2006). Seismic vulnerability estimation of the building considering seismic environment and local site condition. Acta Seismologica Sinica 19(3): 292-298 (in Chinese with English abstract).

Zhao L, Chen Q and Lu Z Q (1999). Study on nonlinear random response of reinforced concrete structures. Eng Mech 16(5): 21-32 (in Chinese with English abstract). 